\title{
Micropropagation of potato (Solanum tuberosum L.) var. Atlantic on various culture media composition
}

\author{
OCP Pradana ${ }^{1^{*}}$, D Maulida ${ }^{1}$ and SN Andini ${ }^{1}$ \\ Crop Production Department, Politeknik Negeri Lampung, Soekarno-Hatta Street \\ Number 10, Rajabasa District, Bandar Lampung City, Lampung Province, Indonesia, \\ 35144 \\ *Corresponding author: onnypradana@polinela.ac.id
}

\begin{abstract}
Potato is included in one of the three most important crops globally after paddy and wheat because it contributes to staple food for humans around the world. In Indonesia, potato prioritizes its development because of non-rice carbohydrate sources and potential in food diversification programs. In Lampung, potato productivity decreased significantly from 2017 to 2018 , resulting in a negative growth rate $(-33 \%)$. One of the factors that cause the low productivity of potatoes is the limited availability of superior seeds. Micropropagation can be an alternative to solve this problem. This research aimed to investigate the growth response of potato var Atlantic on various culture media and obtain the most appropriate culture media for potato shoots induction and multiplication. This research was conducted at the Plant Tissue Culture Laboratory, Politeknik Negeri Lampung, from June-September 2020. Treatments were single arranged in a completely randomized design with three replications, and each replication consisted of three culture bottles containing one explant. Data analysis using ANOVA and HSD test in $5 \%$ alpha. Based on the result of this research, it can be concluded that the potato var Atlantic culture showed different responses on the various components of culture media, and MS media with $0.5 \mathrm{mg} \mathrm{l}^{-1} 2$-iP is the most appropriate culture media for potato micropropagation.
\end{abstract}

\section{Introduction}

The potato plant (Solanum tuberosum L.) is a group of root vegetables rich in vitamin C, minerals, and potassium. At the world level, this plant is included in one of the three most important plants globally because it contributes as a staple food for humans around the world [1]. In Indonesia, potato plants also prioritize their development because they are sources of non-rice carbohydrates and have potential in food diversification programs [2]. In recent years, the trend of potato demand has increased in line with the increasing population and the development of industries that require potatoes as raw material. This has led to the expansion of potato cultivation and increased demand quality potato seeds [3]. From 2014-2018, Indonesia's potato production tended to decline, namely around 1.3 million tons in 2014, then decreased to 1.2 million tons in 2015 and 2016. In 2017 the production declined again to 1.1 million tons, then in 2018 , the production will again increase to 1.2 million tons [4]. In Lampung Province, potato production tends to increase by 441 tonnes (2014), increasing to 464 tonnes (2015). Furthermore, in 2016 potato production in Lampung decreased to 362 tons, then decreased again to 336 in 2017, and in 2018 there was a significant increase in production (608 tons). However, the productivity of potatoes in Lampung is inversely related to production. Potato productivity in Lampung has decreased significantly from 2017 to 2018, from 16 tonnes/ha to 10,67 
tonnes/ha, resulting in a negative growth rate of $-33 \%$ [4]. Thus, the increase in potato production in Lampung is not caused by high plant productivity.

One of the factors causing the low productivity of potatoes is the lack of availability and superior and quality potato seeds. Constraints that occur in the field show that most farmers currently use the remaining seeds from their previous harvest, which has led to a decline in the quality of potato seeds [3]. Potato plants can be propagated sexually using seeds and vegetatively by tubers. However, this propagation method has disadvantages such as a low multiplication level and a high risk of various diseases [5].

One of the efforts that can be made to overcome this problem is by applying tissue culture techniques to multiply plants (micropropagation). Tissue culture techniques can be a better alternative than conventional methods, to produce true-to-type seedlings on a large scale and in a short time [5]. Also, the seeds produced are free from disease, both diseases caused by viruses, fungi, and bacteria. One of the factors that determine the success in tissue culture is the type and concentration of plant growth regulators used depending on the purpose and stage of the culture. Cytokinins are plantgrowth-promoting hormones involved in the specification of embryonic cells, maintenance of meristematic cells, shoot formation, and vasculature development. Numerous reports ascribe a stimulatory or inhibitory function to cytokinins in different developmental processes such as root growth and branching, control of apical dominance in the shoot, chloroplast development, and leaf senescence [6]. The use of the appropriate culture media and the selection of the right type and concentration of plant growth regulators are crucial in inducing and multiplying potato shoots in vitro. Therefore, it is necessary to find the most appropriate culture media in potato shoots induction and multiplication. This research aimed to investigate the growth response of Atlantic potato varieties on various culture media compositions and to obtain the most appropriate culture media for Atlantic potato varieties shoots induction and multiplication.

\section{Methods}

This research was conducted at the Plant Tissue Culture Laboratory, Politeknik Negeri Lampung, from June to September 2020. The materials needed in this research include planting material (explants) derived from potato plantlets (Solanum tuberosum L.) Atlantic variety (G1) derived from in vitro propagation in SeameoBiotrop Laboratory, Bogor. MS (Murashige and Skoog, 1962) media formulation was used as a culture-based media. Growth regulator (bezyladenin and 2-iP) as treatment. Other supporting materials used include distilled water and sterile water, Tween-20, $1 \mathrm{~N} \mathrm{KOH}, 1 \mathrm{~N}$ $\mathrm{HCl}$, aluminum foil, wrapping, plastic, rubber bands, agar, and sucrose. The tools used at the preparation stage include analytical balance, culture bottles, measuring flasks, Erlenmeyer flasks, pipettes, beakers, measuring cups, spatulas, spatula spoons, $\mathrm{pH}$ meters, stoves, autoclaves, pans, Scottish bottles, and magnetic stirrers. In the initiation stage, the tools used include Laminar Air Flow Cabinet (LAFC), Petri dishes, bunsen lamps, hand sprayers, and dissection tools (scalpel, surgical blade).

Treatments were single arranged in a completely randomized design ( 5 culture media composition: $\mathrm{MS}+\mathrm{Agar} 6 \%, \mathrm{MS}+\mathrm{BA} 1 \mathrm{mg} \mathrm{l}^{-1}, \mathrm{MS}+\mathrm{BA} 2 \mathrm{mg} \mathrm{l}^{-1}, \mathrm{MS}+2$-iP $0.5 \mathrm{mg} \mathrm{l}^{-1}, \mathrm{MS}+2-\mathrm{iP} 1 \mathrm{mg} \mathrm{l}^{-1}$ ) with three replications and each replication consisted of three culture bottles containing one explant. The homogeneity of data was tested using the Barlett test. If the assumption were fulfilled, then analysis of variance is executed, followed by the HSD test in 5\% alpha for mean separation. Laboratory activity includes media preparation and sterilization, culture initiation, culture maintenance, and observation after 8 weeks of incubation.

\section{Result and Discussion}

From the research that has been conducted, it is found that the culture media composition resulted in significantly different responses to the potato var Atlantic culture growth and development (Figure 1). Furthermore, to determine the most appropriate culture media composition, the HSD test was executed on all observation variables, and the following results were obtained (Table 1). 
Table 1. Effect of different culture media composition on potato culture (Solanum tuberosum var Atlantic) growth and development.

\begin{tabular}{|c|c|c|c|c|c|c|}
\hline $\begin{array}{l}\text { Culture media } \\
\text { composition }\end{array}$ & $\begin{array}{l}\text { Number } \\
\text { of shoots }\end{array}$ & $\begin{array}{l}\text { Number of } \\
\text { branches }\end{array}$ & $\begin{array}{l}\text { Number of } \\
\text { nodes }\end{array}$ & $\begin{array}{l}\text { Number of } \\
\text { leaves }\end{array}$ & $\begin{array}{l}\text { Number of } \\
\text { roots }\end{array}$ & $\begin{array}{l}\text { Shoot } \\
\text { lengths }\end{array}$ \\
\hline $\mathrm{MS}+$ Agar 6\% & $1.00 \mathrm{c}$ & $1.11 \mathrm{c}$ & $8.44 \mathrm{c}$ & $5.00 \mathrm{c}$ & $4.66 \mathrm{c}$ & $4.31 \mathrm{~b}$ \\
\hline $\mathrm{MS}+\mathrm{BA} 1 \mathrm{mg} \mathrm{l}^{-1}$ & $1.91 \mathrm{ab}$ & $3.50 \mathrm{~b}$ & $14.91 \mathrm{~b}$ & $11.08 \mathrm{a}$ & $7.33 \mathrm{a}$ & $3.64 \mathrm{c}$ \\
\hline $\mathrm{MS}+\mathrm{BA} 2 \mathrm{mg} \mathrm{l}^{-1}$ & $2.00 \mathrm{a}$ & $3.72 \mathrm{~b}$ & $16.86 \mathrm{a}$ & $11.00 \mathrm{a}$ & $6.27 \mathrm{~b}$ & $3.87 \mathrm{bc}$ \\
\hline $\mathrm{MS}+2-\mathrm{iP} 0.5 \mathrm{mg} \mathrm{l}^{-1}$ & $1.93 \mathrm{a}$ & $4.68 \mathrm{a}$ & $17.75 \mathrm{a}$ & $10.61 \mathrm{a}$ & $7.98 \mathrm{a}$ & $4.98 \mathrm{a}$ \\
\hline $\mathrm{MS}+2-\mathrm{iP} 1 \mathrm{mg} \mathrm{l}^{-1}$ & $1.46 \mathrm{~b}$ & $3.46 \mathrm{~b}$ & $13.13 \mathrm{~b}$ & $7.53 \mathrm{~b}$ & $5.86 \mathrm{~b}$ & $5.36 \mathrm{a}$ \\
\hline HSD at $5 \%$ level & 0.46 & 0.63 & 1.80 & 1.61 & 0.88 & 0.56 \\
\hline
\end{tabular}

Note: Different letters in the column indicate significantly different by HSD at $5 \%$ level of probability.
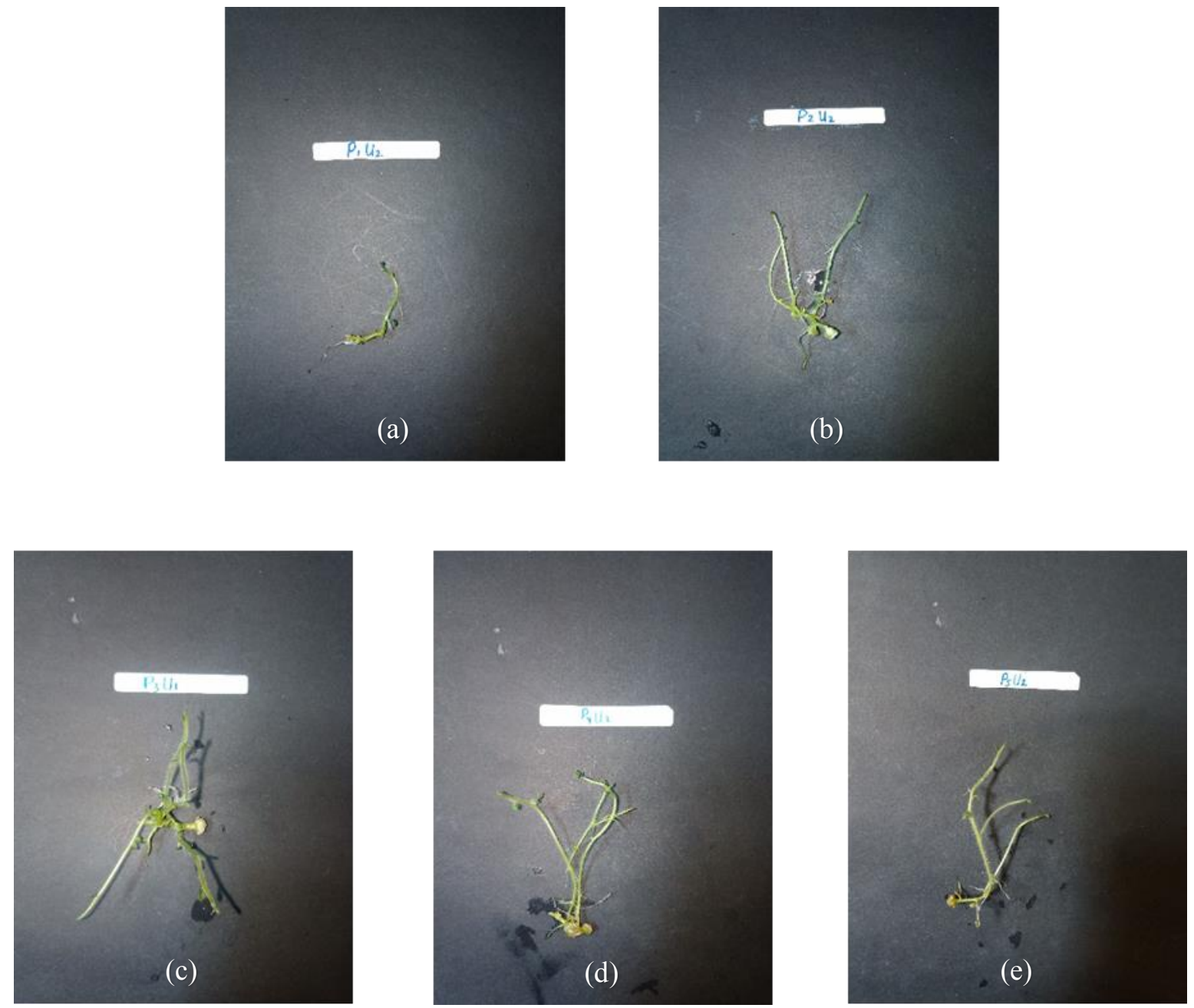

Figure 1. The potato culture var Atlantic growth and development after 8 weeks of incubation. (a) MS + Agar 6\%, (b) MS + BA $1 \mathrm{mg} \mathrm{l}^{-1}$, (c) MS + BA $2 \mathrm{mg} \mathrm{l}^{-1}$, (d) MS + 2-iP $0.5 \mathrm{mg} \mathrm{l}^{-1}$, (e) MS + 2-iP 1 $\mathrm{mg} 1^{-1}$. 


\subsection{Number of shoots}

Based on the results of the HSD test analysis, it can be concluded that media MS + BA $2 \mathrm{mg} \mathrm{l}^{-1}$ and MS + 2-iP $0.5 \mathrm{mg} \mathrm{l}^{-1}$ is the most appropriate culture media composition for producing the number of shoots per explant, and this value is significantly different with another culture media composition (Figure 2). These research results are in line with the results of Munggarani (2018) research, the treatment media MS + BAP $1-2 \mathrm{mg} \mathrm{l}^{-1}$ and MS + 2-iP $1-2 \mathrm{mg}^{-1}$ showed a similar performance to the number of shoots produced [7]. Motallebiazar (2011), reported that a similar number of potato shoots were obtained on media MS + BAP $2 \mathrm{mg} \mathrm{l}^{-1}$ [8]. Kazemiani (2012), also reported that on potato culture cv Agria, the number of lateral shoots was increased by using $2 \mathrm{mg} / \mathrm{l}$ BAP. However, the main shoot length was a decline by BAP addition on culture media [11]. Mohapatra and Batra (2017), found that the maximum number of shoots was obtained when $2 \mathrm{mg} \mathrm{l}^{-1}$ BAP was used [5].

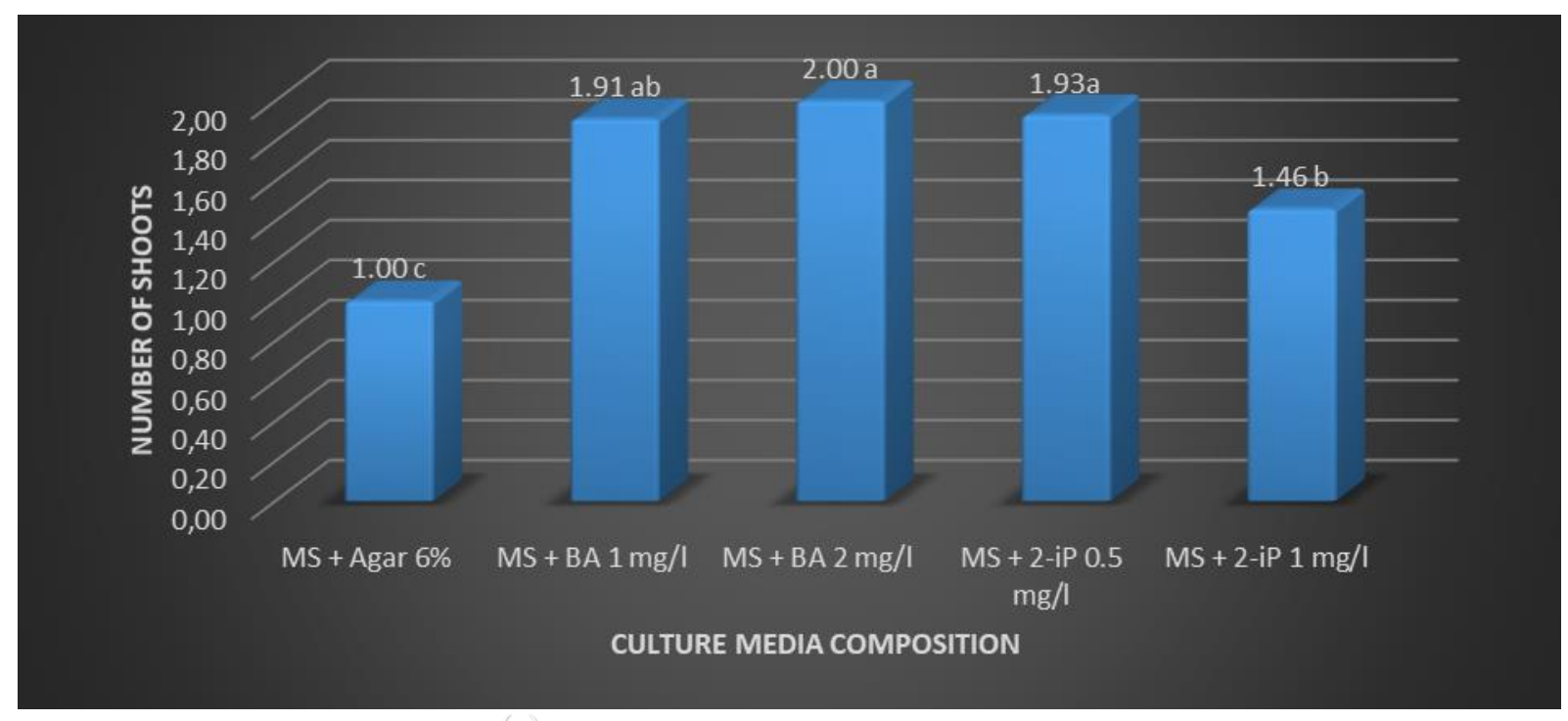

Figure 2. Effects of culture media composition on potato var Atlantic shoot number. Mean followed by the same letter (s) in a column are not significantly different by HSD at 5\% level of probability.

\subsection{Number of branches}

Based on the HSD test analysis results, it can be concluded that media MS $+2-\mathrm{iP} 0.5 \mathrm{mg} \mathrm{l}^{-1}$ is the most appropriate culture media composition for producing the number of branches per explant and this value is significantly different from another culture media composition (Figure 3). These research results are in line with the results of research conducted by Munggarani (2018), the treatment media MS + BAP $1-2 \mathrm{mg}^{-1}$ and MS + 2-iP $1-2 \mathrm{mg} \mathrm{l}^{-1}$ gave no significant difference to the number of branches produced [7]. 


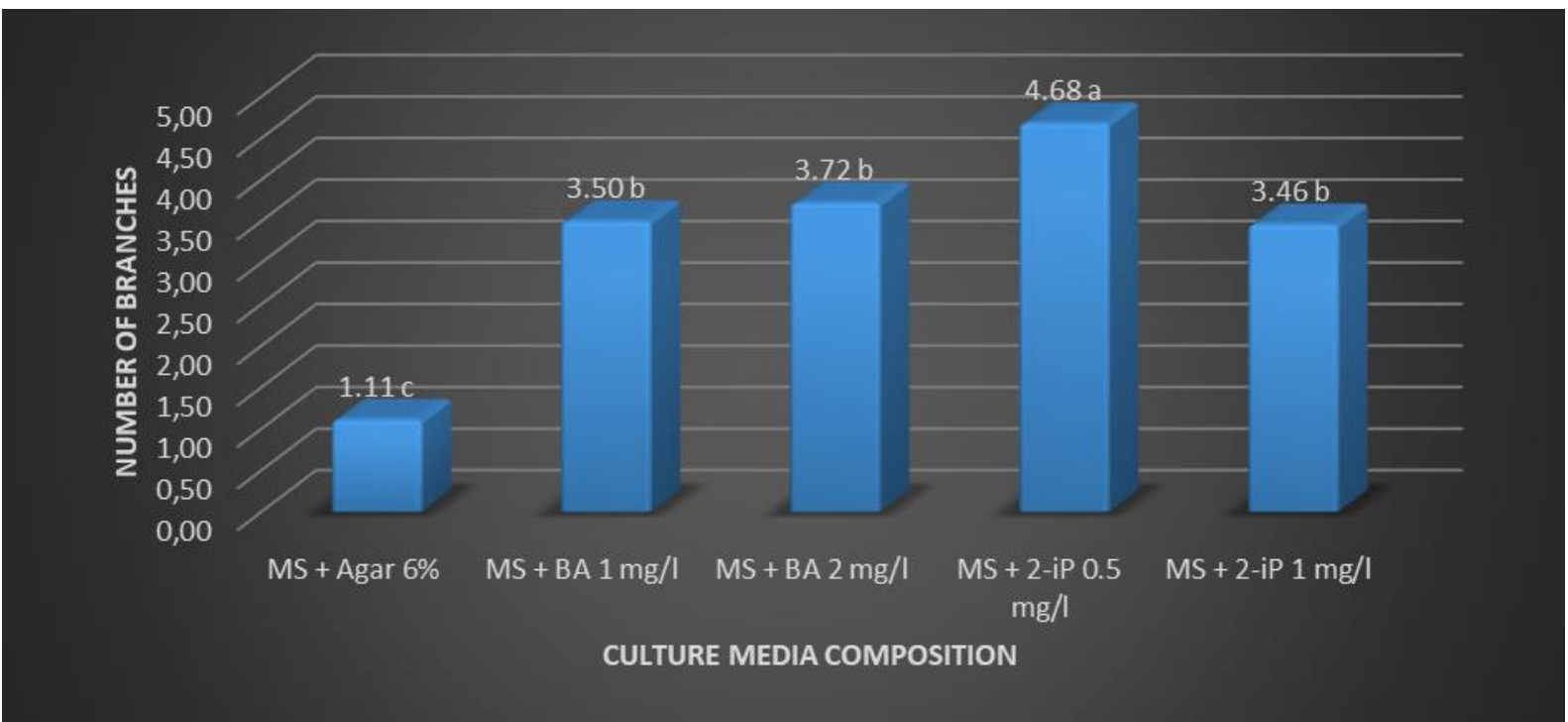

Figure 3. Effects of culture media composition on potato var Atlantic branches number. Mean followed by the same letter (s) in a column are not significantly different by HSD at a $5 \%$ level of probability.

\subsection{Number of nodes}

Based on the results of the HSD test analysis, it can be concluded that media MS + BA $2 \mathrm{mg} \mathrm{l}^{-1}$ and $\mathrm{MS}+2$-iP $0.5 \mathrm{mg} \mathrm{l}^{-1}$ is the most appropriate culture media composition for producing the number of nodes per explant, and this value is significantly different with another culture media composition (Figure 4). Similar results were obtained by Rudiyanto (2016), on red potato culture. In their research, the highest number of nodes was found in the MS culture media, with $0.5 \mathrm{mg} \mathrm{l}^{-1} 2$-iP [9].

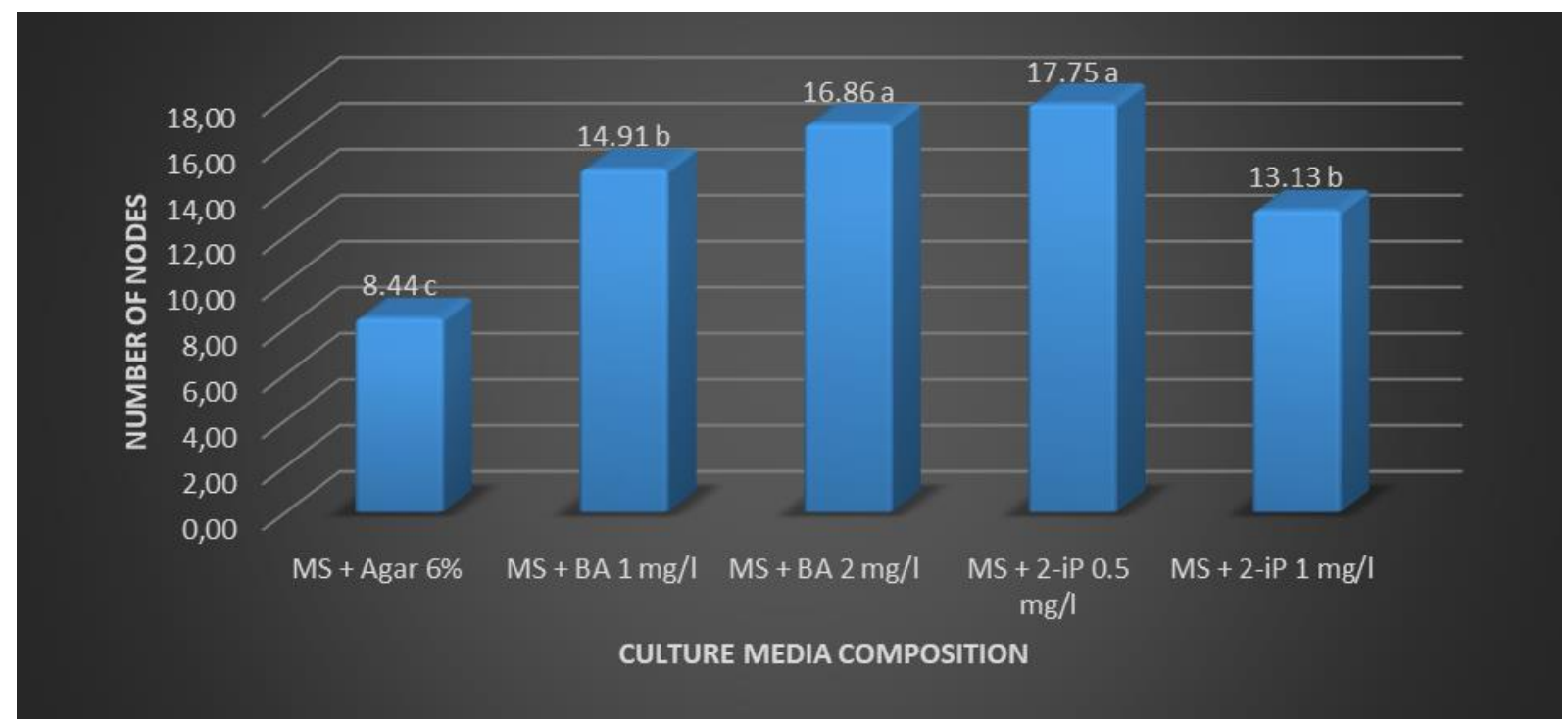

Figure 4. Effects of culture media composition on potato var Atlantic nodes number. Mean followed by the same letter (s) in a column are not significantly different by HSD at a $5 \%$ level of probability.

3.4. Number of leaves

Based on the results of the HSD test analysis, it can be concluded that media MS + BA $1 \mathrm{mg} \mathrm{l}^{-1}$, MS + BA $2 \mathrm{mg} \mathrm{l}^{-1} 1$, and MS +2 -iP $0.5 \mathrm{mg} \mathrm{l}^{-1}$ are the most appropriate culture media composition for 
producing the number of leaves per explant and this value is significantly different with another culture media composition (Figure 5).

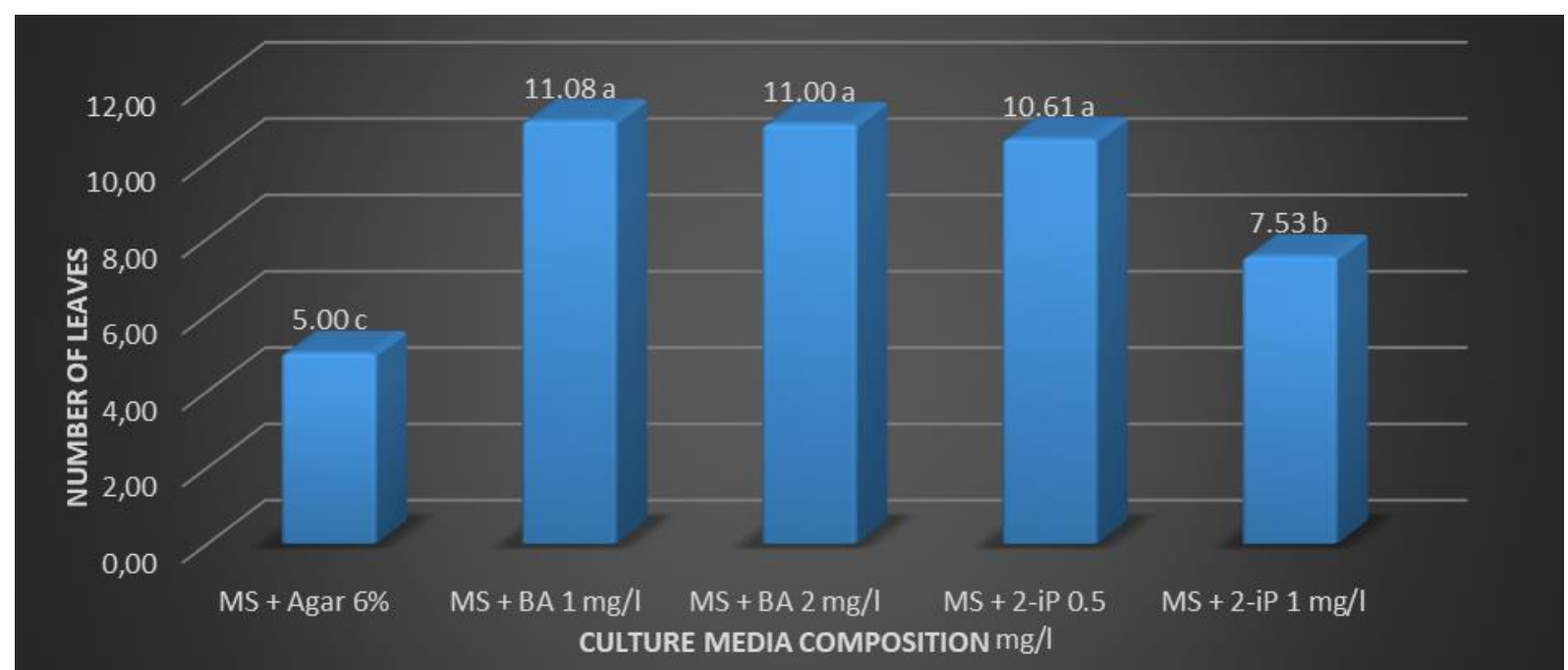

Figure 5. Effects of culture media composition on potato var Atlantic leaves a number. Mean followed by the same letter (s) in a column are not significantly different by HSD at a 5\% level of probability.

Rudiyanto (2016), reported that the leaves number of red potato cultures obtained in MS culture media with $0.5 \mathrm{mg} \mathrm{l}^{-1} 2$-iP, and this value is significantly different from other treatments [9]. Munggarani (2018) stated that cytokinins' addition showed a higher number of leaves in the potato meristem culture of JalaIpam variety compared to media without cytokinins [7].

\subsection{Number of roots}

Based on the results of the HSD test analysis, it can be concluded that media MS + BA $1 \mathrm{mg} \mathrm{l}^{-1}$ and MS + 2-iP $0.5 \mathrm{mg} \mathrm{l}^{-1}$ are the most appropriate culture media composition for producing the number of roots per explant, and this value is significantly different with another culture media composition (Figure 6).

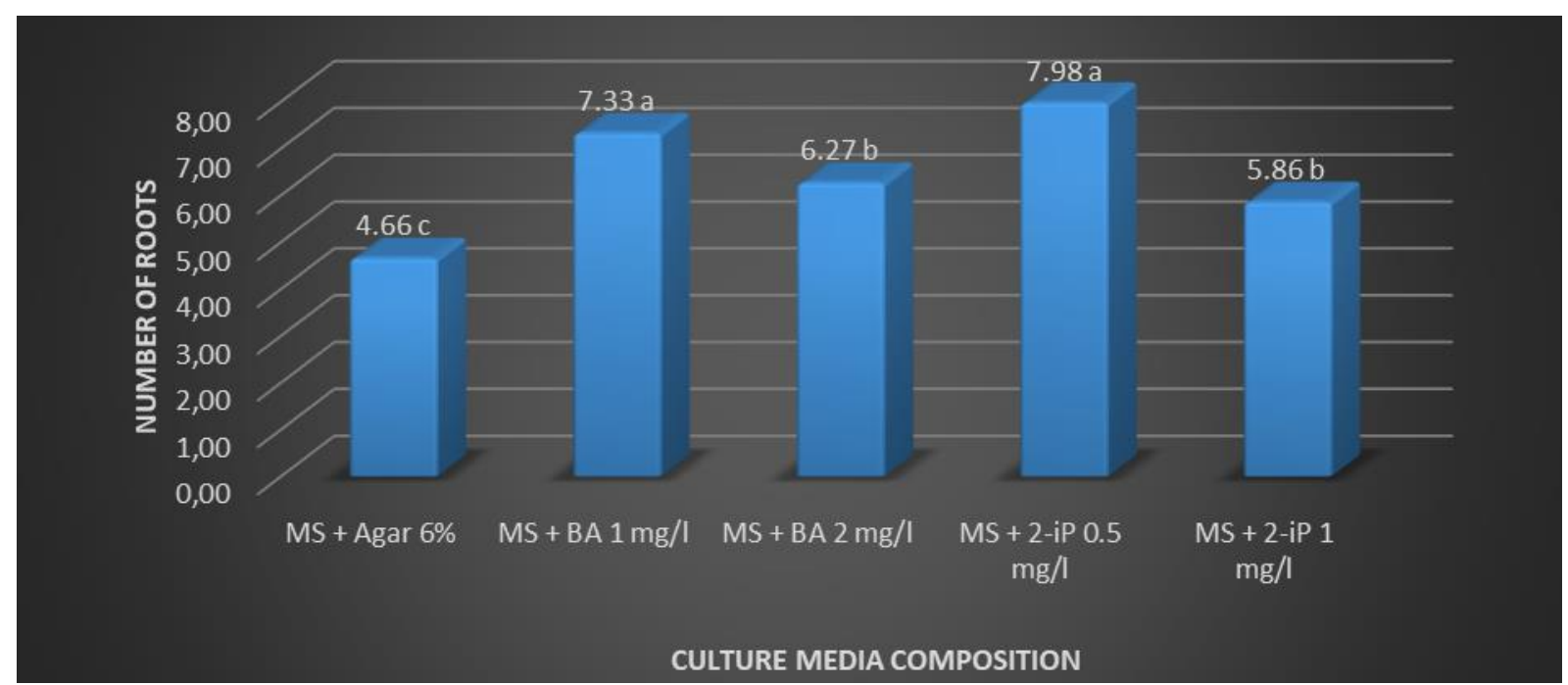

Figure 6. Effects of culture media composition on potato var Atlantic roots number. Mean followed by the same letter (s) in a column are not significantly different by HSD at a $5 \%$ level of probability. 
Generally, cytokinins do not affect the process of root formation and the number of roots. However, there are endogenous auxins produced in the plant, then transported to the base of the stem, so that roots are formed [9]. Auxin is a primary plant hormone that is involved in various developmental processes. In addition to biosynthesis ad degradation, polar auxin transport, the directional cell to cell transport of auxin, is a significant process determining the spatial distribution [10].

\subsection{Shoot lengths}

Based on the results of the HSD test analysis, it can be concluded that media MS + 2-iP $0.5 \mathrm{mg} \mathrm{l}^{-1}$ and $\mathrm{MS}+2-\mathrm{iP} 1 \mathrm{mg} \mathrm{l}^{-1}$ is the most appropriate culture media composition for producing shoot lengths per explant, and this value is significantly different with another culture media composition (Figure 7).

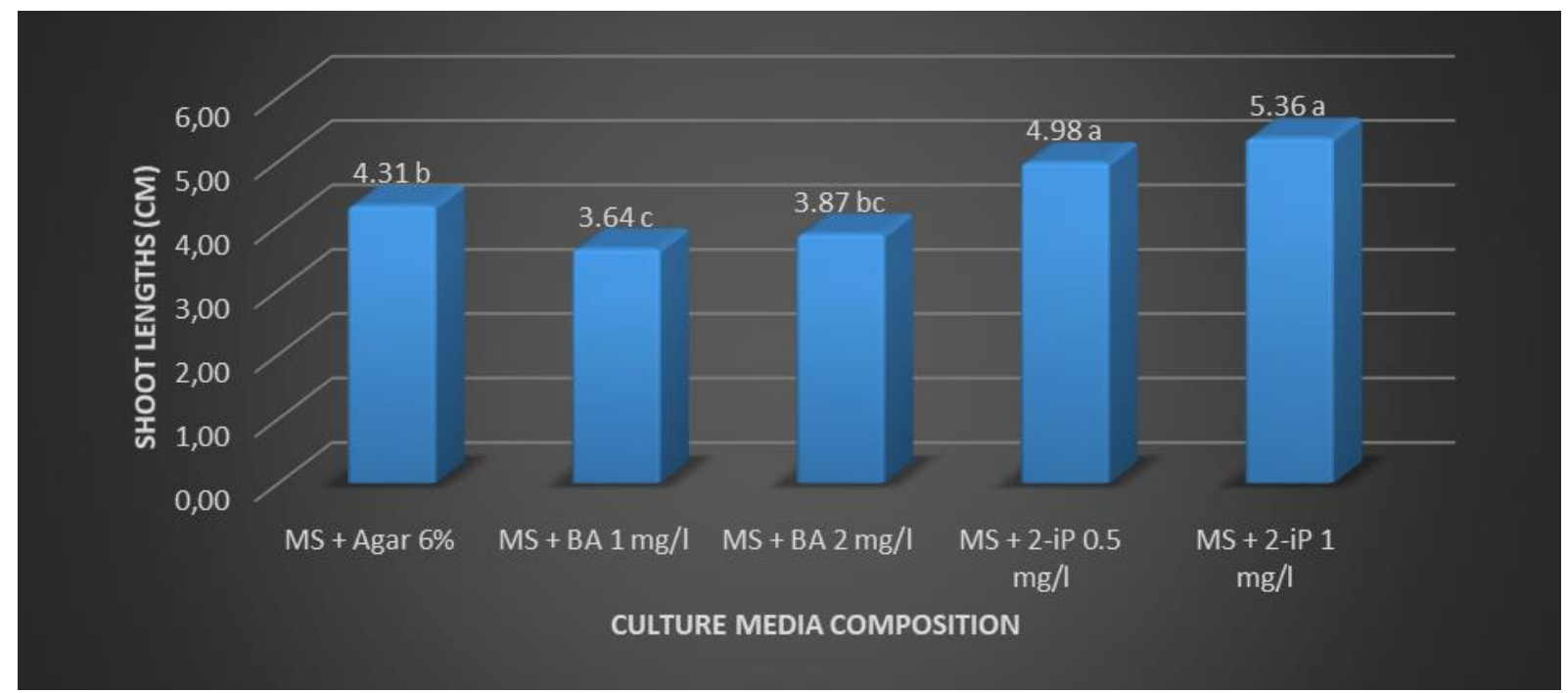

Figure 7. Effects of culture media composition on potato var Atlantic shoot lengths. Mean followed by the same letter (s) in a column are not significantly different by HSD at a 5\% level of probability.

The addition of cytokinins (kinetin, 2-iP, and BA) with high concentrations $\left(2 \mathrm{mg}^{-1}\right)$ tends to cause slow shoot height growth [9]. Munggarani (2018) also reported that the addition of different cytokines in the concentration range of $1-2 \mathrm{mg} \mathrm{l}^{-1}$ resulted in lower shoot height than media without cytokinins in the potato meristem culture Jala Ipam variety [7].

\section{Conclusion}

Based on the result of this research, it can be concluded that the potato var Atlantic culture showed different responses on the various components of culture media, and MS media with $0.5 \mathrm{mg} \mathrm{l}^{-1} 2$-iP is the most appropriate culture media for potato micropropagation.

\section{Acknowledgments}

The authors expressed the gratitude to Politeknik Negeri Lampung as a funder in this research through the POLINELA DIPA 2020 Research Competitive Grant program.

\section{References}

[1] Josseph N, Anbazhagan M, and Srinivasan S 2015 In Vitro Growth of Potato Plant (In Vitro Tuberization) International Journal of Current Science 17: 29-36

[2] Karjadi A K 2016 Tissue Culture and Micropropagation of Potato (Solanum tuberosum L.) Vegetable Crops Research Institute Lembang Bandung 
[3] Furnawanthi I, DeviantiS J, Nauly D, MardiyantoR, and ElyaM 2017 Growth Response of Potato Explants (Solanumtuberosum L.) Variety A $\backslash \mathrm{P}-\mathrm{ZZ4}$ to Mannitol as Conservation Media In Vitro Proceedings of The 2017 National Seminar Faculty of Agriculture UMJ "Sustainable Agriculture and Herbal Plants in Indonesia" pp 244-252

[4] Badan Pusat Statistik Indonesia 2020<https://bps.go.id/subject/55/hortikultura. html\#>Retrieved March 19, 2020

[5] Mohapatra P P and Batra V K2017 Tissue Culture of Potato (Solanum tuberosum L.): A Review International Journal of Current Microbiology and Applied Sciences 6 (4): 489-495

[6] Mazid M, Khan T A, and Mohammad F 2011 Cytokinins, A Classical Multifaceted Hormone in Plant System Journal of Stress Physiology \& Biochemistry 7 (4): 347-368.

[7] Munggarani M, Suminar E, Nuraini A, and Mubarok S 2018 Shoots Multiplication of Mericlon Potato on Various Types and Concentrations of Cytokinins Agrologia 7 (2):80-89

[8] Motallebiazzar A, Kazemiani S, Kiumarise F, and Mohaddes N Shoot Proliferation From Node Explants of Potato (Solanum tuberosum cv. Agria) II Effect of Different Concentrations of $\mathrm{NH}_{4} \mathrm{NO}_{3}$, Hydrolyzed Casein, and BAP Romanian Biotechnological Letters 16 (3): 61816186.

[9] Rudiayanto D, Rantau E, and Ermayanti T M 2016 Growth of Red Potato Shoots (Solanumtuberosum L.) Culture on MS Media (Murashige and Skoog) with Concentration and Type of Cytokinin Treatment Proceedings of the XXV National Seminar "Chemistry in Industry and the Environment" Pages 103-112.

[10] Wang Y, Jiao Y 2018 Auxin and Above-Ground Meristems Journal of Experimental Botany 69 (2): 147-154. DOI: $10.1093 / \mathrm{jxb} / \mathrm{erx} 299$

[11] Kazemiani S, Motallebi-Azar A, Mohaddes N, Kiomarsy F, Yarmohammadi F, and Etedali F 2012 Effect of Different Concentrations of Sucrose and BAP in Shoot Proliferation on MS Strength Basal Media in Potato CV Agria South Western Journal of Horticulture, Biology and Environment 3 (1): 63-72. 